\title{
How does innovation work within the developmental network state? New data on public-private agreements in a U.S. Department of Energy laboratory
}

MATTHEW R. KELLER", FRED BLOGK ${ }^{* *}$ MARIAN NEGOITA

\section{Abstract}

The value of the Department of Energy (DOE)-owned national laboratories to the U.S. national innovation system has long been a subject of debate. Advocates have drawn attention to the central role of the labs in the development of technologies including advanced batteries, solar energy breakthroughs, imaging technologies, and various IT endeavors, among others. Critics have recurrently suggested that the labs' innovative capacities have been undermined by a lack of engagement with commercial firms and managerial tactics. Perhaps surprisingly, what has often been missing from the debate is a thorough review of data on the public-private partnerships in which the labs engage with private firms. This paper draws on heretofore non-public data on one type of contractual arrangement - Work-For-Others (WFO) agreements - in which the labs perform contract work for private firms. We review 10 years of WFO data for a single DOE laboratory. Our analysis provides an initial picture of the surprisingly diverse geography and array of firms that employed the labs as contract R\&D providers, as well as of key characteristics of these agreements. Although our data capture only a single laboratory's agreements, the findings reinforce the importance of looking at the complex, overlapping network of programs within the U.S. federal system that support private sector innovation.

Keywords: Innovation. Developmental States. Networked Industrial Policy. Public-Private Partnerships. United States Government.

\footnotetext{
* Southern Methodist University, EUA

${ }^{* *}$ University of California, EUA

*** Social Policy Research Associates, EUA

- The authors thank Ellyn Stroud and Haley High for research assistance
} 


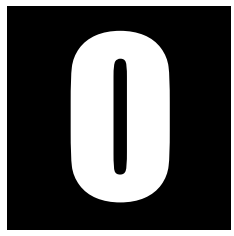

ver the last generation, technological innovation has become increasingly collaborative in nature, as large firms in an array of industries have de-verticalized their research, development, and production processes (Davis, 2011) and shifted toward "networked" or "open" innovation and production strategies that involve strategic alliances with external parties (Chesbrough, 2006; Powell et al., 2005). At the same time, research has increasingly documented how innovative technologies often arise from the combination of multiple specializations, skills, and knowledges that are often fostered by inter-organizational collaborations (Hargadon, 2003; Block; Keller, 2009; Hage, 2012). Indeed, recent research has shown that even in an earlier era when vertical integration dominated the strategies of U.S. firms, many of the most productive research labslike Thomas Edison's "invention factory" and Bell Labs - were organized in ways that enabled cross-cutting collaborations to flourish (Hargadon, 2003; Gertner, 2010).

Given that the U.S. has often been regarded as "the most innovative country in the world" (as a recent World Bank report put it (Gill; Raiser, 2012), the U.S. government's approach to fostering innovative ventures has often been a key touchstone in debates about innovation and industrial policies. Some nations have sought to strengthen American-style institutions and emulate its policies, ranging from bolstering the venture capital sector to modeling intellectual property regimes; from copying specific technology development programs to attempting to create the conditions for the "next Silicon Valley". But how we should interpret the U.S. government's approach to innovation remains deeply disputed. In the international and domestic political arenas, the notion that the U.S. is structured like a "liberal market economy" (Hall; Soskice, 2001) - that 
its innovative dynamism arises from its emphasis of market mechanisms and limited government "intervention" - is pervasive, and reinforced by U.S. policy-makers' long-established tendency to push market reforms in international policy-making venues.

More recent research, however, has documented the extensive involvement, across a wide range of industries, of U.S. government programs and policies in innovative technological developments- a trend that has accelerated since the early 1980s (Block; Keller, 2009; 2011; Mazzucato, 2013). To be sure, the U.S. government had been heavily involved in industries such as aerospace and computer-based technologies (including the development of the architecture for the internet) since World War II. But in the late 1970s and early 1980s, concerns over U.S. competitiveness generated a series of laws and programs that transformed the government's role in supporting innovative ventures (Block, 2008; Berman, 2014; Keller; Block, 2013). As a result, there has been steadily increasing involvement by both military and non-military government programs in supporting award-winning innovative technologies across a wide range of industries (Block; Keller, 2009), while industry case studies have traced deep federal involvement in fields including pharmaceuticals (Cockburn; Henderson, 2001; Vallas; Kleinman; Biscotti, 2011), biotechnology (Hurt, 2011), nanotechnology, green energy, and even the core components of Apple and Microsoft's market-leading technologies (Fong, 2001; Mazzucato, 2013).

The structure of this post-1980 Federal involvement has not, however, been channeled through traditional industrial policy mechanisms that revolve around centralized planning or supporting "industrial champions" among domestic firms. Rather, the U.S. government has developed a decentralized, diverse, and dynamic set of programs that support a vast array of efforts to overcome technical obstacles and develop novel technologies 
- efforts that often rely on network collaborations between or among government, private industry, and university partners. These decentralized initiatives certainly include the well-known use of procurement contracts and a series of grant funding opportunities provided by agencies like the National Institutes of Health (NIH) and the National Science Foundation (NSF). But there is a much wider array of programs that support scientific and technological projects, often organized around a "connected science" model (Bonvillian, 2004) that fosters the development of collaborative expert networks, or which corrects "network failures" (Schrank; Whitford, 2012) in efforts to generate novel technical solutions.

There are numerous institutional mechanisms through which the U.S. government fosters these kinds of developmental networks. Many of those mechanisms have been explored in scholarly work (Block; Keller, 2011) and in governmental reporting mechanisms - though the latter are rarely focused on the network capacities of relevant programs. In this article, our aim is to shed light on the inner-workings of the U.S. developmental network state by analyzing new data on Work-For-Others (WFO) agreements, a rarely-studied mechanism for public-private collaborations inside the U.S. national laboratory system managed by the Department of Energy - an increasingly consequential developmental agency. ${ }^{1}$

The remainder of this article proceeds in three parts. First, we briefly review the Department of Energy's role in the U.S. national innovation system, focusing on a persistent push toward engagement with private firms since the 1990s. Second, we present a snapshot of the DOE's public-private collaborations through a first look at data on a particular contractual mechanism - Work-For-Others (WFO) agreements - in which

\footnotetext{
${ }^{1}$ Although the Department of Energy has long maintained a robust R\&D portfolio, its budget and its role in technology development was magnified by the 2009 "stimulus" bill, which committed roughly US $\$ 90$ billion to green energy investments, much of which was managed by the Department.
} 
private firms pay federal laboratories to access their expertise and equipment. Though WFOs are only one possible mechanism for private firms to make use of government resources, we believe they provide a revealing look into the U.S. government's "developmental network" approach in their demonstration of the range and type of firms drawing on federal resources, and in the layered support mechanisms surrounding their use. Finally, we conclude with several lessons for innovation policy and for understanding the emergent role of developmental support systems for innovative industries.

\section{A Brief History of the Department of Energy's Developmental Arc}

Over roughly the last thirty-five years, the U.S. Department of Energy (DOE) laboratories - once initiated to manage and safeguard the U.S.'s nuclear weapons - have been a central site of efforts to deepen engagements between government scientists and the commercial sector. Beginning most notably with the Stevenson-Wydler Act of 1980, a series of legislative developments promoted collaboration between the labs and private sector agencies. Over time, various contractual mechanisms for public-private partnerships were initiated, including Cooperative Research and Development Agreements (CRADAs) which involve joint contributions from the DOE and private partners; Work-For-Others (WFO) agreements, in which an external partner reimburses a DOE lab for R\&D work; non-proprietary or proprietary user-facility agreements that enable non-federal partners to access lab equipment and scientists; and most recently Agreements for Commercializing Technology (ACT), a pilot program designed to lower barriers to collaboration with private firms. These contractual mechanisms provide one pillar of a complementary series of broader, largely decentra- 
lized policies designed to promote public sector engagement with private firms. At a more aggregate level, the Federal Technology Transfer Act of $1986^{2}$ chartered the Federal Laboratory Consortium for Technology Transfer, a "forum to develop strategies and opportunities for linking laboratory mission technologies and expertise with the marketplace. ${ }^{\prime 3}$ And individual labs have initiated a range of commercially-oriented tactics, including technology transfer offices, venture funds to foster the commercialization of lab technologies, and employee release programs which allow entrepreneurial lab scientists to pursue commercially-focused technologies (Crow; Bozeman, 1998; Walsh; Kirchoff, 2002; Markusen; Oden, 1996; Schact, 2012).

These efforts to push the labs toward the commercial market have been subjected to sharp scrutiny in a U.S. political environment dominated by market-centered rhetoric. By the mid-1990s, the Galvin Commission, appointed by President Bill Clinton to review lab management, was suggesting "corporatizing" the laboratories to avoid DOE "micromanagement" that was alleged to inhibit the labs' productivity and innovation capacity (Task Force on Alternative Futures for the Department of Energy National Laboratories, 1995). Other critics in the late 1990s and early 2000s suggested that the shift toward commercial markets served as a form of "corporate welfare," and that extending government engagement with private firms distorted market competition (Lawler, 1996). Even accounts that viewed the laboratories as important contributors to the U.S. economy tended to suggest reforms were necessary to enable their

\footnotetext{
${ }^{2}$ The 1986 Act also authorized CRADAs and provided incentives for individual lab scientists to collaborate with private sector actors. More broadly, government agencies have been formally authorized to perform work for other government bodies since the Economy Act of 1932, which "allows federal agencies to obtain goods and services from other federal agencies as long as the work cannot be provided as conveniently and cheaply by the private sector." (GAO 1989). The Department of Energy typically dates its own authority to perform contract work for non-federal agencies to provisions in the Atomic Energy Act of 1954.

${ }^{3} \mathrm{http}: / /$ www.federallabs.org/flc/home/about/ (all websites listed last accessed 31 October 2016).
} 
potentials to be unleashed (Winebrake, 1992; Bozeman, 1994). While some individual laboratories have been praised as success stories - Sandia National Laboratory, for instance, has long been regarded as a successful example of commercial engagement - the more common assertion has been that the laboratories significantly underperform relative to their resources and skill capacities.

Although there are exceptions (Crow; Bozeman, 1998; Jaffe; Lerner, 2001; Nemet; Kammen, 2007), the labs' contributions to the U.S. innovation system have continued to be relatively neglected in academic scholarship, and often regarded in skeptical terms within the political domain. Skepticism is perhaps particularly rife among policy-centered organizations. For example, a recent report issued by the Information Technology and Innovation Foundation, the Center for American Progress, and the Heritage Foundation - organizations which cross the political spectrum - forcefully argued that the labs "have not kept pace" with a rapidly changing innovation environment, and that their "tether to the market is weak" (ITIF, CAP, Heritage 2014). Such skepticism is not rare; a 2013 report on the labs by the Clean Air Task Force (CATF) and the Energy Innovation Reform Project (EIRP) - NGOs focused on mitigating pollution and promoting energy innovation, respectively - argued that the DOE, including the labs, "continues to underperform against expectations with respect to advancing new energy technologies in the marketplace." Among other critiques, it argued that the DOE's "institutional structure inhibits innovation"; that a lack of coordination and technology silos within the laboratories inhibit cross-fertilization of ideas; that the laboratories were insufficiently responsive to the private sector; and that DOE micromanagement hinders innovation (CATF; EIRP, 2013). This followed an earlier report, jointly prepared by CATF with the Center for Science, Policy, and Outcomes (CSPO), that doubted the Department of Energy's ability to effectively de- 
ploy "stimulus" funds (from the American Reinvestment and Recovery Act of 2009) to foster green technology development (CSPO; CATF, 2009).

By contrast, a series of recent reports have suggested that the DOE has played a consequential role in industry advances and downward price trends. Mundaca and Richter (2015), for instance, document a range of positive initial effects of "stimulus" funding on green energy technologies and markets, while the Department of Energy (2016) has traced how "decades of investment" by government and industry have positively affected technology trajectories and lowered technology prices in wind, solar PV, electric vehicles, and energy-efficient lighting.

Indeed, what is surprising about the confident diagnoses that often emerge from reform-oriented analyses is that they are rarely accompanied by thorough data on the specific programs and contractual arrangements of the labs. In many respects, the operations and effects of many of those programs are remarkably under-studied. ${ }^{4}$ This is not a novel claim; more than a decade ago, one analysis of accounts of the energy research and development (ER\&D) innovation system noted that "much of the literature on the state of the ER\&D system ignores the lacunae in the relevant information, and arguments are often advanced as applicable to the whole system while being based on data and analysis relating to only a part of it" (Sagar; Holdren, 2002, p. 467). In part, the problem has been fostered by the Department of Energy itself: the DOE has not, for instance, publicly released data on several of the specific public-private contractual mechanisms, while information made available on other programs is posted in obscure databases which do not allow an integrated overview of projects. ${ }^{5}$ This ar-

\footnotetext{
${ }^{4}$ Each of the aforementioned reports also argues that even when programs are evaluated, the metrics employed essentially measure the wrong things. These suggestions mirror a broader debate about appropriate metrics within academic and policy communities that provided impetus for the initiation of the NSF's Science of Science and Innovation Policy program (SciSIP). ${ }^{5}$ CRADA reports are archived at http://www.osti.gov/scitech; it would be generous to say that the system is not user-friendly. There is no public archive of WFO agreements.
} 
ticle represents an initial effort to redress a significant data gap on public-private partnerships by presenting, to our knowledge, the first account of Work-For-Others agreements signed with private firms at a single Department of Energy Laboratory. We obtained information on WFO contracts from the Lawrence Berkeley National Laboratory (LBNL) for the years 2003-2013. LBNL is a medium-sized lab within the federal system, with expertise in areas including biosciences, computing science, energy sciences and technologies, and physical science. ${ }^{6}$ LBNL is one of 10 Department of Energy laboratories that receive more than five percent of laboratory costs through WFO reimbursements from non-DOE parties (Department of Energy, 2011). LBNL is not the most prolific lab in terms of public-private partnerships; Sandia National Laboratory far outpaces other labs in terms of dollar value ${ }^{7}$ and percentage of annual laboratory costs covered by WFO agreements. ${ }^{8}$ By comparison, LBNL's WFO portfolio has typically generated about one-eighth the financial returns of Sandia's. Moreover, as has been well documented, most WFO agreements are intra-governmental in nature, with the Department of Defense the largest contractor. For the fiscal years 2007-2010, between 7-11\% of income from WFOs across the Department of Energy's laboratories were from non-federal sponsors (Department of Energy 2011).

While acknowledging these limits, the data nevertheless represent the only extant public window into the firms that outsource R\&D work to Department of Energy laboratories. As such, we believe this initial data begins to fill a glaring omission in debates on the role of government pro-

\footnotetext{
${ }^{6}$ http://www.lbl.gov/research-areas/

${ }^{7}$ For instance, in Fiscal Years 2007-2010, Sandia reported between $\$ 800-900$ million in annual WFO reimbursements (2000 adjusted dollars). The next most prolific laboratories typically averaged between $\$ 200-300$ million in annual reimbursements. Lawrence Berkeley typically averaged slightly more than $\$ 100$ million in WFO reimbursements during these years (Department of Energy 2011).

${ }^{8}$ The DOE reports that Sandia covered approximately 38\% of its laboratory costs through WFOs in FY 2010. LBNL covered approximately 16\% (Department of Energy 2011).
} 
grams in fostering private sector innovation more generally, and concerning the roles and impacts of the Department of Energy laboratories' engagement with private sector firms more specifically. Given that it has not been clear which kinds of private firms, in what fields, have been willing to expend their own resources to access personnel and equipment at government laboratories, precisely evaluating the structures, outcomes and importance of such programs has been virtually impossible.

\section{Who Contracts with Public Labs?}

The data provided to us by Lawrence Berkeley National Laboratory included WFO agreements with private sector partners signed from FY 2003-2013. The data included firm names, brief descriptions of work, the dates of the agreements, and the amount of each individual contract. Intra-governmental and public-sector agreements were excluded since we were primarily interested in the characteristics of private firms that contract with the labs. ${ }^{9}$

As Charts 1 and 2 show, the number and size of private sector WFO contracts initiated in any given year varies, but on average, LBNL enters into approximately 40 agreements per year (most are multi-year agreements), with a sharp drop during the financial crisis of 2007-2009. Annual WFO contract reimbursements average approximately US $\$ 6.7$ million, and the size of individual contracts ranges from roughly US \$3 million to an occasional small contract as low as just over US $\$ 1,000$. Many of the contracts are large: twelve of the agreements exceeded $\$ 1$ million in

\footnotetext{
${ }^{9}$ Our agreement with LBNL stipulated that in order to access the data, we would not reveal the details of the specific firm involved alongside the contract amount unless those details were already in the public domain. We also obtained several years of data on WFOs across all DOE laboratories through a Freedom-of-Information-Act (FOIA) request to the Department of Energy. We used this data as a verification tool.
} 
value, and an additional seventeen agreements were between $\$ 500,000$ and $\$ 1$ million, typically spread over multiple years. The funds received from private sector partners - as opposed to other government agenciesis a distinct minority in the laboratory's overall WFO portfolio. An audit performed by the Department of Energy suggests that between 2009 and 2011, annual funding from WFOs at LBNL averaged approximately $\$ 118$ million (DOE IG, 2013). Hence, agreements with private sector firms would comprise roughly only 5-6\% of the lab's overall WFO portfolio - a figure roughly consistent with other Department of Energy laboratories. ${ }^{10}$ Hence, WFOs are a modest portion of the lab's revenues.
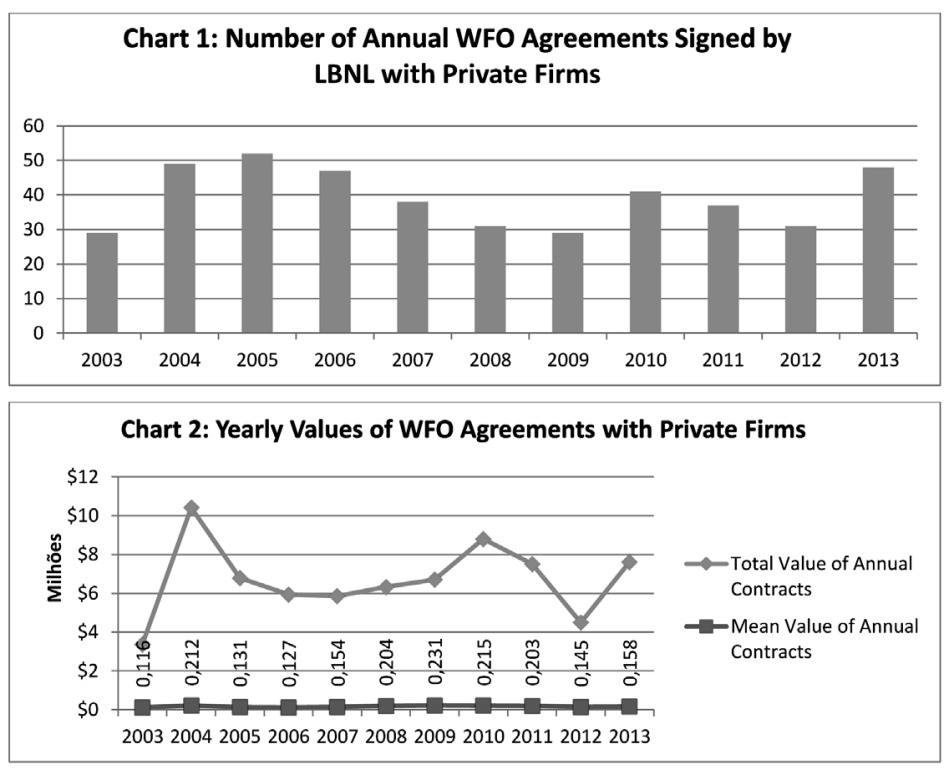

\footnotetext{
${ }^{10}$ The DOE recently reported that annual WFO contracts with "non-federal" partners consisted of between $7-11 \%$ of all WFO contracts for the fiscal years 2007-2010, but the Department did not specify how many of these non-federal contracts were with private firms, as opposed to public universities, state and local governments, or other non-federal entities (DOE 2013).
} 
Chart 3 shows the widely-ranging sizes of firms using WFO's to access lab expertise. On the one hand, a perhaps surprisingly large percentage of WFO contracts are with Fortune 500 firms or their subsidiaries. While it is clear that pressures associated with financialization led many large firms to outsource parts of their R\&D operations to external partners, these are nevertheless the firms that have the budgetary resources that would enable them to invest in the often-expensive equipment and expertise that is available through the labs. Yet, nearly $30 \%$ of WFO agreements are signed not just with large firms, but with the largest 500 firms.

On the other hand, a substantial proportion of WFOs are with smaller firms. ${ }^{11}$ Although it is less surprising that small technology firms would seek to collaborate with specialized counterparties who can provide complementary skills and knowledge, it is nevertheless well established that small businesses often have difficulty navigating the arduous process of contracting with U.S. government agencies (Wessner, 2008). As Walsh and Kirchoff (2002, p. 134) put it, contractual agreements with the federal government, including WFOs "often work well for large firms, but the high costs of negotiating such agreements make them very expensive so they have been used sparingly by small entrepreneurial enterprises."

Why, then, do so many small firms engage with the contractually-unwieldy WFO? The data suggest an answer that hints at another element of the U.S. developmental state: its 'layered' quality. Strikingly, WFO agreements with small firms are frequently tied to firms and projects supported by yet another federal program: the Small Business Innovation Research (SBIR) and the related Small Business Technology Transfer (STTR)

${ }^{11}$ We use the U.S. Small Business Administration's definition of a small firm as one that has fewer than 500 employees. 
program. ${ }^{12}$ As the chart shows, a nearly equal percentage of WFO agreements, compared to Fortune 500 firms, was comprised of firms that were current or recent prior SBIR or STTR awardees..$^{13}$ In some of these cases, the WFO contract involves a firm that wins an SBIR award, and then channels a portion of that award into R\&D performed at the government laboratory. This pattern is consistent with suggestions that SBIR and STTR awards effectively facilitate small firms' access to complementary resources (Keller; Block, 2013; Wessner, 2008). More generally, these kind of overlapping federal support linkages suggest that WFOs should be seen as one aspect of a broader, decentralized, developmental network of programs that congeal in ways that may be elusive to analyses that take single programs as their unit of analysis. Indeed, a majority of the SBIR and STTR awards won by WFO firms came from agencies other than the Department of Energy.

If we compare the WFO contracts across firm types - using Fortune 500 and small-firm SBIR/STTR awardees as core categories of analysis - some finer-grained details of firm-lab relations also emerge. Contracts with Fortune 500 firms are, on average, larger in size, slightly longer in duration, and Fortune 500 firms were more likely to enter into multiple WFO contracts (see Table 1). That means that although the proportion of

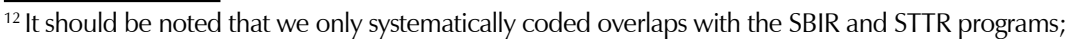
government databases make it difficult to definitively track cross-program linkages at the national, state, and local levels. However, SBIR appears to be the most central overlap, hence a reasonable proxy - even if its sole use understates connections to other government programs. The STTR program funds collaborations between a government laboratory or university and a small firm.

${ }^{13}$ We used SBIR/STTR status as a proxy for small firms. Due to data limitations, we cannot assert that each of these awards is a direct transfer of funds from SBIR; even when the project titles are exact matches in the SBIR database, it is possible that funds directed to the lab are from another pot of funds within the firm's budget (STTR awards can be clearly linked to the lab, since they are explicitly joint agreements between a firm and LBNL). Moreover, there are additional complexities in that a single firm in some instances had multiple simultaneous contracts with the labs, some of which were SBIR awards and some of which were not. Because we were more interested in comparing the sizes of firms entering into WFO agreements, we counted firms in this category either if this project was clearly an SBIR/STTR-supported project, or if the firm had won SBIR or STTR awards in the prior five years.
} 


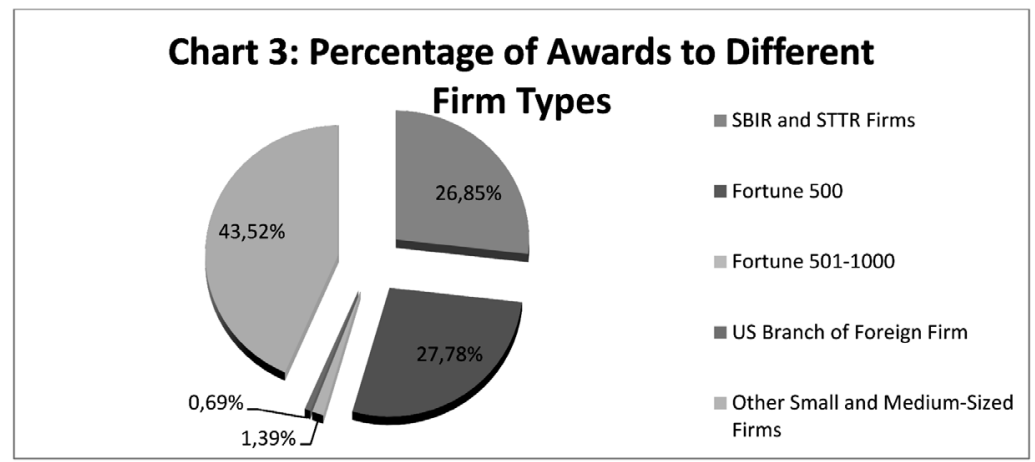

agreements signed with Fortune 500 compared to smaller firms is roughly equivalent, there are more individual SBIR/STTR firms than Fortune 500 companies employing the WFO contractual mechanism. That is, relations with larger companies at LBNL appear to be more dense and ongoing, whereas small firm contracts are more likely to be one-off or occasional arrangements tied to specific projects, and often contingent upon funding by another federal program. ${ }^{14}$

Table 1. Characteristics of Fortune 500 and SBIR/STTR WFO Contracts

\begin{tabular}{|c|c|c|c|}
\hline & $\begin{array}{c}\text { Average number of } \\
\text { contracts per firm, } \\
\mathbf{2 0 0 3 - 1 3}\end{array}$ & $\begin{array}{c}\text { Average per } \\
\text { contract funding }\end{array}$ & $\begin{array}{c}\text { Average contract } \\
\text { length }\end{array}$ \\
\hline Fortune 500 Firms & 3.1 & $\$ 197,708$ & 1.98 years \\
\hline SBIR/STTR Firms & 1.8 & $\$ 124,036$ & 1.58 years \\
\hline
\end{tabular}

${ }^{14}$ The average of SBIR/STTR firms is skewed upward by a single firm, Radiation Monitoring Devices, Inc. (RMD). RMD engaged in 27 WFOs over the 10 year period, with an average value of roughly US $\$ 80,000$ per contract. RMD is also a frequent SBIR award winner. 
If the firms involved in these contracts are relatively diverse - ranging from very large to relatively small - so too are the industries in which they operate. ${ }^{15}$ Firms with their primary business in the biotech and pharmaceutical industries were the most frequent contractors of any specific field; a substantial number of these WFOs involved private firms' participation in industrial consortia that use technologies developed or managed by the labs. For instance, the PHENIX (Python-based Hierarchical EnviroNment for Integrated Xtallography) consortium, based around software for computational crystallography developed with NIH funding, involves collaboration between multiple government laboratories as well as a series of industrial partners. ${ }^{16}$ Another set of contracts involve firms that collaborate with the Berkeley Center for Structural Biology, which employs the "Advanced Light Source" - a spectroscopic probe which enables scientists to map rapidly-occurring chemical reactions. ${ }^{17}$

Contracts with pharmaceutical and biotech firms are far from a majority, however, with slightly smaller shares of agreements drawn from the oil and gas industry, semi- and superconductors, and an array of green technology fields including advanced batteries, solar PV, energy-efficient building technologies, geothermal, and scattered agreements in fields like carbon sequestration and cellulosic biomass. Imaging technologies - particularly for oil and gas exploration - play a role in these other fields, as well. But the contracts encompass a broader range of fields including work with advanced materials and nanotechnologies, computer modeling, scintillators, thin-film solar, and radiation shields for unmanned aircraft. Indeed, contracts certainly encompass traditional high-tech firms and industries, but they also include what might be less expected projects

\footnotetext{
${ }^{15}$ We categorized primary area of operations based on firms' self-descriptions, rather than the specific technology involved in the contract.

${ }^{16} \mathrm{http}: / /$ www2.lbl.gov/tt/techs/lbnl1770.html

${ }^{17} \mathrm{http}: / /$ bcsb-web-2.als.lbl.gov/wordpress/
} 
with, for instance, benchmarking energy efficiency objectives for the retailer Target, and optimization of air purification systems spun off from a NASA project. ${ }^{18}$ To be sure, the lab's role in some cases is for a relatively minor portion of an overall technology development process or project. But these kinds of modest contributions are neither rare nor unimportant in a networked innovation economy in which multiple parties may contribute different sub-components of a larger project. Indeed, although performing a detailed analysis of the trajectory of each of the roughly 430 LBNL WFO projects is beyond the scope of this paper, the SBIR/STTR awards and LBNL's contributions appear to be part of a complex, interwoven government support structure for private technology firms. Among the smaller firms, it is common to find cases where firms rely on revenue streams that comprise a combination of federal funding, private financing from venture capitalists or other sources, and/or contributions from university-based researchers.

The fields noted above only touch upon the diversity of agreements, with further contracts with firms working in areas ranging from aerospace and lasers to spectroscopy and genomics. But they are intended to convey the range of technological fields that engage with just a single laboratory.

\section{The Geography of Lab Support}

It has long been documented that geographic clustering tends to foster innovation in a variety of technology-intensive industries (Saxenian, 1996; Porter, 1998), and that spatial proximity, under the right conditions, can facilitate the kinds of trusting, interpersonal exchanges that can stimulate innovation (Piore; Sabel, 1984; Porter et al., 2009). In Alfred Marshall's oft-quoted phrase, it is often in these face-to-face, interactive

\footnotetext{
${ }^{18}$ Described here: http://spinoff.nasa.gov/Spinoff2013/cg_4.html and here: http://www.nist. gov/tpo/publications/upload/Federal-Lab-TT-Report-FY2009.pdf
} 
local settings where "the secrets of industry are in the air." Do the national labs serve a similarly local pool of firms through WFOs, contributing to a more geographically bounded regional cluster? Or is their support more of a nationally-encompassing resource? To answer the question, we compiled data on WFO firm locations from company websites, business registration data filed with state governments, and a variety of industry databases and third-party websites.

The answer is decidedly mixed. Of the 218 firms that engaged in at least one WFO from 2003-13, nearly half (103) were headquartered in California or had a main R\&D facility in the state; a strong majority of California firms, in turn, were located in the Bay Area and Silicon Valleythat is, in close proximity to the lab - with a smaller cluster of firms in Southern California, notably including San Diego-area biotech companies. That roughly half of the firms are California-based is not a surprise given the centrality of California-based firms to technology-intensive industries like ICT, biotechnology and pharmaceuticals. And it certainly appears that the labs play an occasional supporting role to large, well-known companies within those industries through WFOs with firms including Intel, Hewlett-Packard, and Google as well as Chevron and Bristol-Myers-Squibb, among others. Notably, however, only a relatively modest percentage of the California-headquartered firms using WFOs - about 15\% - were Fortune 1000 firms. Instead, California-based firms tended to be smaller, local startups - some of which have themselves spun-out of projects developed at Lawrence Berkeley. California-based firms also tended to have more WFO contracts per firm than their out-of-state counterparts. That is, although this data covers only one contractual mechanisms for public-private partnerships, WFOs appear to embed the labs as a support mechanism for a local cluster of smaller, entrepreneurial firms, but also ex- 
tend the lab's reach to broader, more nationally encompassing networks through medium and larger-sized firms. ${ }^{19}$

To be sure, this analysis is an extremely rough proxy for geographic proximity. Some firms headquartered in more distant locations, particularly large firms, have subsidiaries, branches, or research offices in California. And large firms in industries like pharmaceuticals, in which acquisitions are a key strategy for bolstering technology portfolios, typically keep careful tabs on developments in the Bay Area and southern California alike. This is itself, in part, a function of the "networked" innovation economy, in which firms often rely on contributors, consultants, or partnerships in multiple locations. To illustrate the complexities, take just one smaller WFO firm, Optobionics, Inc. Although headquartered in Wheaton, Illinois, the firm - which developed technologies related to retinal implants -was at the time of its WFO contract also working out of a space in Palo Alto that was leased from another technology firm, Nanosys, Inc. Nanosys's then-CEO, in turn, was a co-developer of key Optobionics' technologies and the brother of the Optobionics CEO. Both firms received venture funding from some of the same sources. ${ }^{20}$ Hence, although technically an out-of-state firm, Optobionicswas deeply embedded in northern California.

\footnotetext{
${ }^{19} \mathrm{~A}$ larger percentage of out-of-state small firms were SBIR award winners, suggesting that federal programs were one likely linkage between the California-based lab and some geographically distant firms.

${ }^{20}$ Nanosys disclosed the rental agreement and relation in a 2004 filing to the SEC: http://sec. edgar-online.com/nanosys-inc/s-1-securities-registration-statement/2004/04/22/section34. aspx , or here: http://www.nasdaq.com/markets/ipos/filing.ashx?filingid=2873754. Both firms received venture investments from Polaris Ventures, among others (noted in Miller et al., 2005, p. 203). Optobionics eventually filed for bankruptcy in 2007, after failing to receive sufficient funding for Phase III clinical trials (Matson, 2010), but its name and intellectual property was later re-acquired by its founder. A successor organization using the same name is now headquartered in Glen Ellyn, Illinois.
} 
While we acknowledge these complexities, ${ }^{21}$ we nevertheless believe that tracing the main locations for, and the associated attributes of these firms serves a useful, albeit rough proxy in capturing characteristics of lab support. In that regard, Lawrence Berkeley National Lab's WFO contracts appear to be locally embedded, but nationally connected: built around a core regional constituency of small and medium-sized technology firms (including spin-outs from the labs themselves), but connected to a broader, nationally-encompassing innovation system - primarily through ties with large firms and via ancillary federal programs that channel or familiarize smaller firms with resources available through federally-funded research laboratories like LNBL.

\section{Discussion}

As with the lab's geographic embeddedness, there are limits to what we can claim on the basis of data from a single government laboratory. We have nevertheless provided an initial window into a heretofore unanalyzed category of an important public-private contractual mechanism. Our review suggests that in many, if not most cases, the uses of the lab's equipment and expertise should be termed "supplementary" - they advance or refine technologies developed elsewhere, or provide models or maps intended to help external parties orient and refine ongoing research and product development efforts. But in an era of decentralized production in which innovations have precisely emerged from the contributions of multiple parties with distinctive skills and knowledges, the potential

\footnotetext{
${ }^{21}$ Although we have used a smaller firm example, Fortune 1000 and multi-national firms though a relatively modest portion of the sample - are the most tenuously coded, since they are rarely strictly bound by their headquarters location (indeed, many firms register in states like Delaware for tax purposes).
} 
value of these collaborative inputs should not be assumed to be minor. ${ }^{22}$ Hence, though we are unable to measure the centrality of these agreements to various innovative outcomes based on data currently available, it would be difficult to imagine the labs' contributions were not valuable to the private firms involved given that, first, private firms fund the work; second, that many firms enter into multiple contracts or renew contracts; and third, that these patterns prevail despite the fact that the contractual mechanism is regarded as bureaucratically burdensome.

Nevertheless, although private firms do pay the costs associated with WFOs, determining accurate pricing for services rendered by the labs is complicated. Many reports on the labs emphasize the burdens placed on private firms, describing WFOs as "costly" due to their bureaucratic unwieldiness or the financial expenses involved - particularly for small firms (for example, GAO, 2009). Yet the labs often provide rare or unique expertise or technologies that are not widely available in the "market." The absence of private-sector competition is, in fact, one of the criteria the labs are mandated to ascertain prior to approving a WFO agreement. ${ }^{23}$ This means that in cases where there is competition for a contract, a laboratory's primary competitors are not private firms, but other federal research facilities. ${ }^{24}$ Accordingly, determining a fair price for services is extremely complicated, since it is not clear how one should accurately price services in the absence of legitimate market competition. Indeed, pricing and cost recovery issues have been central to recent DOE Inspector General reports on lab agreements with external partners (see DOE IG, 2013).

\footnotetext{
${ }^{22}$ For an analysis of another Department of Energy contractual mechanism (Cooperative Research and Development Agreements (CRADAs), in which the federal lab and a private firm both contribute resources to a joint project) that emphasizes these multiple roles, see Crow and Bozeman 1998.

${ }^{23}$ The GAO has noted, however, that procedures for reviewing these criteria are often left to the labs themselves, and are not often verified by central DOE administrators (GAO, 2013).

${ }^{24}$ See, especially, NAPA 2013 for its discussion of "competition".
} 
Perhaps in response to some of the criticisms lodged against the labs' weak ties to the market, in recent years the Department of Energy and some individual labs have initiated a range of programs or services designed to reduce transaction costs as a means to encourage private firms to contract with lab partners. Chief among these is the Agreement for Commercializing Technology (ACT), a pilot program that enables laboratories "a more flexible framework for negotiating intellectual property rights" and greater discretion for negotiating the terms of agreements with private firms. ${ }^{25}$ Others include the DOEs "LabSTAR" program, a "Small Business Voucher Pilot" for clean energy companies. According to the labs, the program allows small firms to apply for up to a $\$ 300,000$ voucher (of a total of $\$ 20$ million funded by the DOE) in support from Lawrence Berkeley, Sandia, or Lawrence Livermore National Laboratories, if companies agree to contribute $20 \%$ of the project costs. ${ }^{26}$ Whether such programs open access to a wider array of partners, or whether they serve to subsidize the costs of outsourcing research and development for private counterparties remains to be seen - a dynamic that is difficult to assess given the challenges involved in determining price for relatively unique services and capacities.

These new programs do, however, point to what appears to be a concerted effort to increase the number of collaborative arrangements with public sector partners. In light of the expansion of such programs, alongside the widespread perception of the rigid and unwieldy nature of the WFO contractual agreement, a puzzle nevertheless remains. Why did the labs serve as routine partners for such a wide variety of firms despite the acknowledged administrative complexities involved? We do know

\footnotetext{
${ }^{25} \mathrm{~A}$ brief overview of ACT's is available at: http://www.federallabs.org/flc/education/t2-mechanisms/mech-profile/?mechanism_id=185

${ }^{26}$ On LABStar, see: http://newscenter.lbl.gov/2015/07/09/bay-area-national-laboratories-jointly-launch-new-small-business-voucher-pilot-for-emerging-cleantech-companies/. Other recent public-private ventures include CalCharge and Cyclotron Road.
} 
that external collaborations are extremely risky for firms, which must constantly search for competent and trustworthy network partners in a starkly competitive environment in which the opportunism and limited competence of external counter-parties are continual risks (Schrank; Whitford, 2012). The uncertainty involved in these dynamics has made the presence of what Lester and Piore (2004) term "collaborative public spaces" - free flowing spaces where diverse parties can share information without excessive risk of opportunism - extremely important. Though many government programs designed to foster collaboration fail to create such spaces (Keller; Negoita, 2013), governments and universities are nevertheless likely candidates to host them precisely because they are to some degree insulated from the opportunism characteristic of market competition (Lester; Piore, 2004; Powell, 1998), and because governments have the potential to serve as relatively honest brokers under the right conditions, such as those suggested in Peter Evans' (1995) account of "embedded autonomy." Effective government labs, we suspect, are able to play the role of trustworthy, competent, and relatively neutral collaborator for many firms, likely offsetting some concerns related to costs and contractual burdens. ${ }^{27}$

Of course, not all labs are equally stable nor effective in these ways, nor are the personnel, knowledge domains and equipment deemed valuable by private companies equally distributed among government research facilities. Moreover, measuring the degree to which individual laboratories are, indeed, "tethered to the market," and assessing the costs and benefits of the programs that link them to private sector partners remains a challenge. But since the full range of data on collaborative efforts at the

\footnotetext{
${ }^{27}$ Lam (2005) has noted that in an era in which the largest corporations favor "open" and "flexible" internal R\&D approaches, many corporations have developed "extended internal labor markets" which rely upon partnerships with more stable university scientists to compensate for their own more unstable human resource environments. It seems probable the national labs serve a similar function.
} 
labs has not been public, it has been difficult to establish the range of activities the labs have been engaged in, the precise services they provide, and the ways they may differentially encourage, structure and support collaborations. This article takes an initial step in efforts to shed light on the scope, scale, and mechanisms involved.

\section{Conclusion}

In thinking about how programs like WFOs relate to public policy and the role of the state in fostering innovation, it is important to note that the provision of this type of collaborative support service does not comprise "industrial policy" in the older, pejorative sense of "picking winners." In this case, the impetus for stimulating the chemical reaction, or exploring the properties of thin-film conductors does not come from - nor is it funded by - government. Rather, the labs typically play a facilitative role in supporting new technologies that private firms believe to have market potential, or they foster the improvement of technologies that are already commercially available. The labs do not "pick winners"; they facilitate the development or certify the feasibility of ideas that bubble up from external partners. Moreover, as the presence of the SBIR and STTR awardees suggest, it is not a single program acting alone that is the catalyst for many of these innovative collaborations, but rather a multi-layered, decentralized, and often-overlapping series of programs, agencies, and policies that foster public-private collaborations.

For developing nations or those that wish to emulate aspects of the U.S. innovation environment, some lessons seem clear. First, the U.S.'s innovative capacity has not been built upon large, centralized agencies supporting national champions or forging new technological developments on their own, but on a decentralized, layered set of developmental pro- 
grams that foster the pursuit of multiple technologies and multiple solutions to technological roadblocks. The use of federal research laboratory equipment and personnel through WFOs is just one of an array of such mechanisms, and WFO agreements are permeated with cross-linkages to other sources of support both within and outside the federal government. Hence, although the WFOs are only a small piece of an overall picture, they point to the presence of a new, largely tacit kind of "post-industrial" innovation policy driven by a range of governmental supports and engaged collaborations between private firms, universities, and government technology programs.

Second, although the U.S. government's resources and capacities are not comparable to other nations, the U.S. approach is not entirely structurally different from other "developmental network states" that have successfully fostered economic dynamism in high-tech industries (e.g. O'Riain, 2004; Breznitz, 2007; Negoita; Block, 2012). Forging collaborative networks by limiting opportunism and connecting relevant resources has been a key element of these policies (Wade, 2014), though the agencies playing the facilitative role, and the relevant resources often differ dramatically from case to case (e.g. Mehri, 2015). It seems clear that pathways to a more successful developmental network strategy are not of a "one-size fits all" character, but rather rely on an ability to accurately assess a given nation's capacities and resources - while maintaining sufficient state capacity and autonomy to resist corruption and clientelism (Negoita; Block, 2012).

Finally, in a fiscal environment in which government resources for research and development are under tight constraints even within countries like the U.S., it is particularly unfortunate that many of these programs and the linkages between them remain relatively under-studied. If not handled with caution, reform efforts which seek to further link government 
and university R\&D to the private sector may serve to erode rather than strengthen collaborative public spaces. If not carefully structured, efforts to pursue policies such as reducing corporate taxes to promote private R\&D may serve to cut the legs out from the system of public support that has lent U.S. firms a competitive advantage. While the current data do not allow us to definitively engage those broader questions, they do suggest that even well-intentioned reformist agendas could benefit from expanded data and greater scholarly attention.

Matthew R. Keller is Associate Professor of Sociology at Southern Methodist University, Texas, EUA. \mkeller@smu.edu

Fred Block is Research Professor at the Department of Sociology, in the University of California, Davis. $\$ flblock@ucdavis.edu

Marian Negoíta is PhD in Sociology (University of California-Davis) and Senior Associate at Social Policy Research Associates.

$\measuredangle$ marian_negoita@spra.com

\section{References}

1. BERMAN, E. P. Not Just Neoliberalism: Economization in US Science and Technology Policy. Science, Technology and Human Values, v. 39, n. 3, p. 397-431, 2014.

2. BLOCK, F. L. Swimming against the Current: the Rise of a Hidden Developmental State in the United States. Politics \& Society, v. 36, n. 2, p. 169-206, 2008.

3. BLOCK, F. L.; KELLER, M. R. Where do Innovations come from? Changes in the U.S. Economy, 1970-2006. Socio-Economic Review, v. 7, n. 3, p. 459-83, 2009.

4. BLOCK, F. L.; KELLER, M. R. (eds.). State of Innovation: The U.S. Government's Role in Technology Development. Boulder, CO: Paradigm, 2011. 
5. BONVILLIAN, W. Power Play. The American Interest v. 2, n. 2, p. 39-49, 2006.

6. BOZEMAN, B. Evaluating Government Technology Transfer. Policy Studies Journal, v. 22, n. 2, 322-7, 1994.

7. BREZNITZ, D. Innovation and the State. New Haven: Yale University Press, 2007.

8. CENTER FOR SCIENCE, POLICY, AND OUTCOMES AND THE CLEAN AIR TASK FORCE. Innovation Policy for Climate Change: A Report to the Nation. 2009. Disponível em: http://archive.cspo.org/projects/eisbu/report.pdf

9. CHESBROUGH, H. Open Innovation. Boston, Harvard Business School Press, 2006.

10. CLEAN AIR TASK FORCE AND THE ENERGY INNOVATION REFORM PROJECT. Putting Energy Innovation First: Recommendations to Refocus, Reform, and Restructure the Department of Energy. 2013. Disponível em: http://www.catf. us/resources/publications/files/Putting_Energy_Innovation_First.pdf

11. COCKBURN, I. M.; HENDERSON, R. M. Publicly Funded Science and the Productivity of the Pharmaceutical Industry. In: JAFFE, A. B.; LERNER, J.; STERN, S. (eds.). Innovation Policy and the Economy, Volume 1. Cambridge: MIT Press, 2001.

12. CROW, M.; BOZEMAN, B. Limited by Design: R\&D Laboratories in the U.S. National Innovation System. New York: Columbia University Press, 1998.

13. DAVIS, G. F. Managed by the Markets. Princeton: Princeton University Press, 2011.

14. DOE - DEPARTMENT OF ENERGY. Revolution Now: The Future Arrives for Five Clean Energy Technologies - 2016 Update. Washington: Department of Energy, 2016.

15. DOE - DEPARTMENT OF ENERGY. Work for Others at the National Laboratories: Report for Congress. Washington: Department of Energy, maio 2011.

16. DOE-IG - DEPARTMENT OF ENERGY INSPECTOR GENERAL. Fiscal Year 2011 Audit of the Work Performed Under the Work for Others Program at the Lawrence Berkeley National Laboratory. Audit Report OAS-L-13-10. Washington: Department of Energy Inspector General, 2013.

17. EVANS, P. Embedded Autonomy. Princeton: Princeton University Press, 1995.

18. FONG, G. R. ARPA does Windows: The Defence Underpinning of the PC Revolution. Business \& Politics, v. 3, n. 3, p. 213-37, 2001. 
19. GOVERNMENT ACCOUNTABILITY OFFICE. Technology Transfer: Clearer Priorities and Greater Use of Innovative Approaches Could Increase the Effectiveness of Technology Transfer at Department of Energy Laboratories. Report GAO09-548. Washington: Government Accountability Office, jun. 2009.

20. GOVERNMENT ACCOUNTABILITY OFFICE. National Laboratories: DOE Needs to Improve Oversight of Work Performed by Non-DOE Entities. Report GAO-14-78. Washington: Government Accountability Office, out. 2013.

21. GERTNER, J. The Idea Factory. New York: Penguin, 2012.

22. GILL, I. S.; Raiser, M. Golden Growth: Restoring the Lustre of the European Economic Model. Washington: The World Bank, 2012.

23. HAGE, J. Restoring the Innovative Edge. Stanford: Stanford University Press, 2011.

24. HALL P. A.; Soskice, D. Varieties of Capitalism. Oxford: Oxford University Press, 2001.

25. HARGADON, A. How Breakthroughs Happen. Cambridge: Harvard Business School Press, 2003.

26. HURT, S. The military's hidden hand: examining the dual-use origins of agricultural biotechnology in the American context, 1969-1972. In: BLOCK, F. L.; KELLER, M. R. (eds.), State of Innovation. Boulder: Paradigm, 2011.

27. STEPP, M. et al. Turning the Page: Reimagining the National Labs in the $21^{\text {st }}$ Century Innovation Economy. Nonpartisan Policy Reforms from the Information Technology and Innovation Foundation, the Center for American Progress, and the Heritage Foundation. Washington: ITIF, 2013.

28. JAFFE, A. B. Lerner, J. Reinventing Public R\&D: Patent Policy and the Commercialization of National Laboratories Technologies. The Rand Journal of Economics, v. 32, n. 1, p. 167-98, 2001.

29. KELLER, M. R. The CIA's Pioneering Role in Public Venture Capital Initiatives. In: BLOCK, F. L.; KELLER, M. R. (eds.) State of Innovation. Boulder: Paradigm, 2011.

30. KELLER, M. R.; BLOCK, F. L. Explaining the Transformation of the U.S. Innovation System: the Role of a Small Government Program. Socio-Economic Review, v. 11, n. 4, p. 629-56, 2013.

31. KELLER, M. R.; NEGOITA, M. Correcting Network Failures: The Evolution of U.S. Innovation Policy in the Wind and Advanced Battery Industries. Competition \& Change, v. 17, n. 4, p. 319-38, 2013. 
32. LAM, A. Work Roles and Careers of R\&D Scientists in Network Organizations. Industrial Relation, v. 44, n. 2, p. 242-75, 2005.

33. LAWLER, A. DOE to Industry: So Long, Partner. Science, v. 274, p. 24-6, 4 out. 1996.

34. LESTER, R.; PIORE, M. Innovation: the Missing Dimension. Cambridge, MA, Harvard University Press, 2004.

35. MARKUSEN, A.; ODEN, M. National Laboratories as Business Incubators and Region Builders. Journal of Technology Transfer, v. 21, n. 1-2, 93-108, 1996.

36. MAZZUCATO, M. The Entrepreneurial State. London: Anthem, 2013.

37. MEHRI, D. B. Pockets of Efficiency and the Rise of Iran Auto: Implications for Theories of the Developmental State. Studies in Comparative International Development, v. 50, n. 3, p. 408-32, 2015.

38. MILLER, J. C. et al. The Handbook of Nanotechnology. Hoboken: Wiley, 2004.

39. MUNDACA, L.; RICHTER, J. L. Assessing 'Green Energy' Stimulus Packages: Evidence from U.S. Programs Targeting Renewable Energy. Renewable and Sustainable Energy Reviews v. 42, p. 1174-86, 2015.

40. NATIONAL ACADEMY OF PUBLIC ADMINISTRATION. Positioning DOE's Labs for the Future. Washington: NAPA, 2013.

41. NEGOITA, M.; BLOCK, F. L. Networks and Public Policies in the Global South: the Chilean case and the Future of the Developmental Network State. Studies in Comparative International Development, v. 47, n. 1, p. 1-22, 2012.

42. NEMET, G. F.; KAMMEN, D. M. U.S. energy research and development: Declining investment, increasing need, and the feasibility of expansion. Energy Policy, v. 35, p. 746-55, 2007.

43. Ó RIAIN, S. The politics of High-Tech Growth: Developmental Networks States in the Global Economy. Cambridge: Cambridge University Press, 2004.

44. PIORE, M. J.; SABEL, C. F. The Second Industrial Divide. New York: Basic, 1984.

45. PORTER, M. E. Clusters and the New Economics of Competition. Harvard Business Review, v. 76, n. 6, p. 77-90, 1998.

46. PORTER, K.; WHITTINGTON, K. B.; POWELL, W. W. The Institutional Embeddedness of High-Tech Regions: Relational Foundations of the Boston Biotechnology Community. In: BRESCHI, S.; MALERBA, F. (eds.). Clusters, Networks, and Innovation. New York: Oxford, 2005. p. 261-96. 
47. POWELL, W. W. et al. Network Dynamics and Field Evolution: The Growth of Inter-Organizational Collaboration in the Life Sciences. American Journal of Sociology v. 110, n. 4, p. 1132-205, 2005.

48. SAGAR, A. D.; HOLDREN, J. P. Assessing the Global Energy Innovation System: Some Key Issues. Energy Policy, v. 30, n. 465-9, 2003.

49. SAXENIAN, A. Regional Advantage. Cambridge: Harvard University Press, 1996.

50. SCHACHT, W. Cooperative R\&D: Federal Efforts to Promote Industrial Competitiveness. Washington, DC: Congressional Research Service, 2010.

51. SCHRANK, A.; WHITFORD, J. The Anatomy of Network Failure. Sociological Theory, v. 29, n. 3, p. 151-77, 2012.

52. TASK FORCE ON ALTERNATIVE FUTURES FOR THE DEPARTMENT OF ENERGY NATIONAL LABORATORIES. Alternative Futures for the Department of Energy National Laboratories. Washington DC: Department of Energy, 1995.

53. VALLAS, S. P.; KLEINMAN, D. L.; BISCOTTI, D. Political Structures and the Making of Biotechnology. In: BLOCK, F. L.; KELLER, M. R. (eds.). State of Innovation. Boulder: Paradigm, 2011.

54. WADE, R. H. Market versus State or Market with State: How to Impart Directional Thrust. Development and Change, v. 45, n. 4, p. 777-98, 2014.

55. WALSH, S. T.; KIRCHOFF, B. A. Technology Transfer from Government Labs to Entrepreneurs. Journal of Enterprising Culture, v. 10, n. 2, p. 133-49, 2002.

56. WESSNER, C. W. An Assessment of the Small Business Innovation Research Program. Washington: National Academies Press, 2008.

57. WINEBRAKE, J. J. A Study of Technology Transfer Mechanisms for Federally Funded R\&D. Technology Transfer, v. 17, n. 4, p. 54-61, 1992.

Received: 01.23.2017

Accepted: 05.02.2017 